ŽELJKO KURTELA, Ph.D.

E-mail: zeljko.kurtela@unidu.hr

University of Dubrovnik, Maritime Department

Ćra Carića 4, HR-20000 Dubrovnik, Republic of Croatia

PAVAO KOMADINA, Ph.D.

E-mail: pavao.komadina@pfri.hr

University of Rijeka, Faculty of Maritime Studies

Studentska 2, HR-51000 Rijeka, Republic of Croatia
Transport Engineering

Original Scientific Paper

Accepted: May 13, 2008

Aproved: Dec. 22, 2008

\title{
HARMFULNESS EVALUATION METHOD FOR ON-BOARD WATER BALLAST MANAGEMENT
}

\begin{abstract}
Having identified all the dominant factors and having put together a mosaic of all the factors resulting from a ship's voyage, as well as a number of differently dimensioned criteria, the harmfulness evaluation method for water ballast management on board has been elaborated. By careful analysis of the impact factors to which status elements are adjoined, by the assignment of harmfulness levels to the status elements, by determining difficulty factor values, by introduction of treatment methods i. e. exchange of water ballast, certain characteristic management scenarios according to ship type are developed. $\mathrm{Cu}$ mulative scenarios provide insight into the total harmfulness of water ballast management. The introduction of a comprehensive approach results in the development of different scenarios applicable to all ships. The established harmfulness evaluation method for water ballast management is applicable to all ship types, and it has been tested on various types of ships that were discharging ballast in various ports worldwide.
\end{abstract}

\section{KEY WORDS}

water ballast, management harmfulness, impact factors, status elements, harmfulness levels, management scenarios.

\section{INTRODUCTION}

Transportation of organisms in water ballast and sediments represents one of the biggest threats to marine biodiversity, ecosystems and even human health. Ship's water ballast may contain various phytoplankton and zooplankton organisms (algae, cysts, larvae of shellfish, fish, snails and crabs). For a long time water ballast was considered to be clean; consequently, ballasting and deballasting procedures on board were not treated as potential hazard [1], [7], [8]. Between 11 to 12 billion tonnes of ballast waters are being transported worldwide per annum, and over 7000 of various organisms are carried in these waters [5], [11]. Harmful impacts are the cause of destruction or decrease in fishing, mariculture and relevant shore and processing industry, tourism, and related sectors. Global influence on the world economy is being estimated around 10 billion euro per annum [13]. Transportation of organisms in water ballast represents one of the biggest threats to the world seas and ecosystems nowadays. Introduced organisms may cause irreversible changes in the communities structure, such as repression of autochthon species until their total extinction [14]. Water ballast exchange procedures on open sea are not fully efficient; therefore, any discharge of water ballast in ports has a certain harmful impact on the marine environment. For a maritime country with a wide coastline and many ports where water ballast is discharged the possibility of evaluation of discharged water ballast management harmfulness level is of utmost importance [7]. By an elaborated harmfulness evaluation methodology it is possible, prior to discharge of water ballast from ships, to undertake certain action in water ballast management in order to eliminate or diminish the harmfulness level. Previous research work did not treat the said problem using the methodology set up and elaborated in this paper. A selective approach, namely, to harmfulness evaluation [6], [7], [8], [10], [15] of water ballast management was taken which led to neglect of the dominant factors. Consequently, it was necessary to develop a comprehensive approach that identifies, defines, elaborates and systematically links all the impact factors, status elements, harmfulness levels, difficulty factors and other elements influencing water ballast management.

From the above stated the hypothesis of this paper is derived and set up: selective approach to water ballast management methodology leads to neglect of dominant factors; therefore, a comprehensive approach is required that will identify, define, elaborate and systematically link all impact factors, status elements, harmfulness levels, difficulty factors and other elements influencing water ballast management that are required when determining harmfulness level of water ballast discharged. 


\section{METHODOLOGY OF WATER BALLAST MANAGEMENT}

\subsection{INTRODUCTORY CONSIDERATIONS}

Upon the analysis of water ballast according to the environmental impact criteria, research of exchange and treatment methods, defining and analysis of impact factors, assignment of status elements and determining of harmfulness levels it is possible to analyse and elaborate typical water ballast management scenarios, i. e. harmfulness of the environmental impact.

Management harmfulness can be evaluated through a selective approach or general methodology. The selective approach comprises only a limited segment of management whereas the general methodology i. e. comprehensive approach can evaluate any type of ship during water ballast discharge in any world port, no matter where the water ballast was loaded and where it is being discharged or what exchange procedure or management method is applied on board. Consequently, in further definition of the model a comprehensive approach by general methodology has been applied.

\subsection{WATER BALLAST MANAGEMENT IMPACT FACTORS}

In order to determine the general methodology of water ballast management it is necessary to identify and set up a detailed analysis of all the water ballast management impact factors. The impact factors can be divided into five basic groups: technical factors, operational factors, human factors, standardization factors and natural factors.

The technical factors cover the constructive characteristics of a particular ship and its ballast system and ballast tanks. The terotechnological part that includes the ship maintenance factor is also part of the technical factor. The operational factors cover various operational conditions of a ship during voyage. The standardization factor includes all the rules, regulations, conventions and stipulations referring to and in connection with water ballast management as well as the regulations prescribed by Ship Registers. The human factors comprise the influence of the ship's crew and all other personnel that is not necessarily required on board, but having a direct or indirect influence on the water ballast management. The natural factors include water ballast characteristics and conditions prevailing in ports and at seas during water ballast management.

\section{- Technical Factors}

The technical factors $T F$ comprise the following factors: ship type, ballast management system, ballast tanks, and ballast and tanks maintenance system. These factors include constructional characteristics of the type of ship, hull structure and ballast system with ballast tanks. Apart from these factors that remain permanent during ship exploitation period there is also the terotechnological factor presented within the ship maintenance factor.

$T F_{\text {kolb }}$ - total water ballast quantity factor;

$T F_{\text {sbis }}$ - water ballast status on discharge according to ship type factor;

$T F_{i z t^{-}}$ballast tanks operation factor;

$T F_{m g c t}-$ ballast tanks cleaning possibilities factor;

$T F_{\text {odrz }}$ - ballast system maintenance factor;

$\mathrm{TF}_{\text {stbr }}{ }^{-}$ship age factor.

\section{- Operational factors}

The operational factors $O F$ refer to various operational conditions of the ship during water ballast management.

$O F_{b t e r}$ - factor of loaded ship without water ballast, or ship with permanent water ballast (that is not discharged);

$O F_{u k b l}$ - factor of ship loading water ballast in port area;

$O F_{t r p b}$ - factor of voyage duration in ballast factor;

$O F_{i s b r}$ factor of ship discharging water ballast in port area;

$O F_{\text {bdok }}$ - factor of ship in dry-dock.

\section{- Human factors}

The water ballast management is directly influenced by the human factors. These factors include the ship crew influence as well as the influence of all the other personnel having direct or indirect influence on the ship operations.
$L F_{\text {posb }}$ - ship crew factor;
$L F_{\text {mang }}$ - shipping company management factor.

\section{- Standardization factors}

The standardization factors include all technical, shipbuilding standards, shipping standards and local standards.

$N F_{\text {regb }}$ - Ship Registers standards factor;

$N F_{\text {bwmp }}$ - water ballast management implementation plan factor;

$N F_{\text {imob }}$ - international standards on water ballast factor;

$N F_{\text {lokp }}$ - local standards on water ballast factor;

$N F_{\text {vnad }}$ - maritime country surveillance i. e. port authorities factor.

\section{- Natural factors}

The natural factors comprise various natural factors concerning the sea, operational possibilities of ports, weather conditions that the ship may encounter 
in various phases and which influence the water ballast management.

$$
\begin{aligned}
& P F_{p v e} \text { - open sea weather conditions factor; } \\
& P F_{\text {opdb }} \text { - operational depth of the port of loading } \\
& \text { water ballast factor; } \\
& P F_{\text {orgh }} \text { - sea condition with respect to target organ- } \\
& \text { isms in loading port factor; } \\
& P F_{d d a n} \text { - time of day when water ballast is loaded in } \\
& \quad \text { port factor; } \\
& P F_{\text {kmor }} \text { - sea category in the port of loading water } \\
& \text { ballast factor. }
\end{aligned}
$$

\subsection{STATUS ELEMENTS}

By introducing impact factors, an analysis of relevant factors has been set up to which harmfulness level elements are assigned. Having developed the status elements a mosaic of all the factors influencing the decision-making has been put together and the resulting interactions allow for determining the water ballast management model. The status elements are added to water ballast management impact factors defining thus the possible status of water ballast management impact factors.

\section{Status elements of technical factors}

$-e_{T k b, m v b}$ status element of a ship with small quantity of water ballast;

$-e_{T k b, s v b}$ status element of a ship with medium quantity of water ballast;

$-e_{T k b, v b}$ status element of a ship with large quantity of water ballast.

The quantity of discharged water ballast in port or port area is usually proportional to the quantity of organisms discharged. The status elements are assigned for the following quantities of the total water ballast discharged: $e_{T k b, m v b}<10000 \mathrm{~m}^{3}, e_{T k b, s v b} 10000 \mathrm{~m}^{3}-$ $100000 \mathrm{~m}^{3}, e_{T k b, v v b}>100000 \mathrm{~m}^{3}$.

$-e_{\text {Tsbpis }}$ status element of a ship discharging full water ballast;

$-e_{T s, d i s}$ status element of a ship discharging a part of water ballast;

$-e_{T s b \text { stb }}$ status element of a ship with mostly permanent water ballast.

$-e_{T i z, m b t}$ status element of a ship with relatively smaller number of ballast tanks;

$-e_{T z, b b t}$ status element of a ship with relatively larger number of ballast tanks.

$-\boldsymbol{e}_{T m c \text { lak }} \quad$ status element of water ballast tanks with relatively easier cleaning options;

$-e_{\text {Tmctez }}$ status element of water ballast tanks with relatively more difficult cleaning options;

$-e_{\text {Tod, bez }}$ status element of a ship without water ballast system within the ship maintenance system; $-e_{\text {Tod,dil }}$

status element of a ship with water ballast system partially included within the ship maintenance system;

$-e_{\text {Tod,pot }}$ status element of a ship with a complete maintenance system.

$-e_{\text {Ts, nov }}$ status element of a new ship;

$-e_{T s ; d j s}$

$-e_{\text {Tst.pst }}$ status element of a partially old ship;

status element of an old ship.

\section{Status elements of operational factors}

$-e_{O t r, b v b}$ status element of a loaded ship without water ballast or with permanent ballast that is not discharged;

$-e_{\text {Ouk, vpk }}$ status element of a ship loading water ballast with relatively shorter overflow period;

$-e_{\text {Ouk, vpd }} \quad$ status element of a ship loading water ballast with relatively longer overflow period;

$-e_{\text {Otp,ptk }}$ status element of a relatively shorter voyage in ballast;

$-e_{\text {Otp.pss }}$ status element of a relatively average voyage in ballast;

$-e_{\text {Otp.ptd }}$ status element of a relatively long voyage in ballast;

$-e_{O i s, l b n}$ status element of a ship discharging untreated water ballast in port area;

- $e_{O i s, b t}$ status element of a ship discharging treated water ballast in port area;

$-e_{\text {Odk,sim }}$ status element of a dock releasing tank sediments into sea;

$-e_{\text {Odk,szb }}$ status element of a dock storing sediments from ballast tanks.

\section{Status elements of human factors}

$-e_{L p s, g r m} \quad$ status element of a crew with possible minor error in water ballast management;

$-e_{L p s, g v}$ status element of a crew with possible larger error in water ballast management;

$-e_{\text {Lmn,odn }}$ status element of shipping company management without due concern for water ballast;

$-e_{\text {Lmn,ods }}$ status element of the shipping company management with due concern for water ballast management.

\section{Status elements of standardization factors}

$-e_{\text {Nrqusk }}$ status element of a ship fully complying with standards of Registers;

$-e_{\text {Nrg, neu }} \quad$ status element of a ship in partial discrepancy with standards of Registers;

$-e_{B m p, u s k}$ status element of a ship implementing BWMP;

$-e_{\text {Bmp,neu }}$ status element of a ship with partially implemented BWMP; 
$-e_{\text {Nim,usk }}$ status element of a ship in full compliance with complete water ballast standards;

$-e_{\text {Nim,neu }}$ status element of a ship in discrepancy with complete water ballast standards;

$-e_{N l k, s t r}$ status element of a port - country with strict local water ballast standards;

$-e_{\text {Nlk,bez }}$ status element of a port - country without local water ballast standards;

- $e_{\text {Nnz bez }}$ status element of a maritime country without surveillance over water ballast management;

$-e_{N n z, d j l}$ status element of a maritime country with partial surveillance over water ballast management; $-e_{\text {Nnzpot }}$ status element of a maritime country with full surveillance over water ballast management.

\section{Status elements of natural factors}

$-e_{P v r, m o m}$ status element of weather conditions allowing for water ballast management;

- $e_{P v r, m o t}$ status element of weather conditions complicating or preventing water ballast management;

$-e_{P d b . l v d}$ status element for water ballast loading port with relatively big depth;

$-e_{P d b . \text { Imd }}$ status element for water ballast loading port with relatively smaller depth;

Table 1 - Harmfulness levels of status elements

\begin{tabular}{|c|c|c|c|c|c|c|c|}
\hline & $\begin{array}{l}\text { Impact } \\
\text { Factors }\end{array}$ & $\begin{array}{c}\text { Status } \\
\text { Elements }\end{array}$ & $\begin{array}{c}\text { Harmfulness } \\
\text { Level }\end{array}$ & & $\begin{array}{l}\text { ipact } \\
\text { ctors }\end{array}$ & $\begin{array}{c}\text { Status } \\
\text { Elements }\end{array}$ & $\begin{array}{c}\text { Harmfulness } \\
\text { Level }\end{array}$ \\
\hline \multirow{16}{*}{ 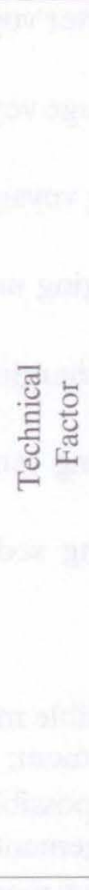 } & \multirow{3}{*}{$T F_{k o l b}$} & $e_{T k b, m v b}$ & $\oplus$ & \multirow{4}{*}{ 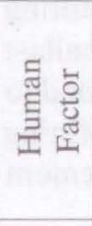 } & \multirow{2}{*}{$N F_{p o s b}$} & $e_{L p s, g r m}$ & $\oplus$ \\
\hline & & $e_{T k b, s v b}$ & 0 & & & $e_{L p s, g v}$ & 0 \\
\hline & & $e_{T k b, v v b}$ & 0 & & \multirow{2}{*}{$N F_{\text {mang }}$} & $e_{L m n, o d n}$ & 0 \\
\hline & \multirow{3}{*}{$T F_{\text {sbis }}$} & $e_{T s b, p i s}$ & 0 & & & $e_{\text {Lmn,ods }}$ & $\oplus$ \\
\hline & & $e_{T s b \text {,dis }}$ & 0 & \multirow{11}{*}{ 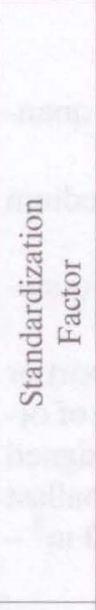 } & \multirow{3}{*}{$N F_{\text {vnad }}$} & $e_{N n z, b e z}$ & 0 \\
\hline & & $e_{T s b, s t b}$ & $\oplus$ & & & $e_{N n z, d j l}$ & 0 \\
\hline & \multirow{2}{*}{$T F_{i z v t}$} & $e_{T i z, m b t}$ & 0 & & & $e_{N n z, p o t}$ & $\oplus$ \\
\hline & & $e_{T i z, v b t}$ & 0 & & \multirow{2}{*}{$N F_{r e g b}$} & $e_{\text {Nrgusk }}$ & $\oplus$ \\
\hline & \multirow{2}{*}{$T F_{m g c t}$} & $e_{\text {Tmc,lak }}$ & $\oplus$ & & & $e_{\text {Nrg,neu }}$ & 0 \\
\hline & & $e_{T m c, t e z}$ & 0 & & \multirow{2}{*}{$N F_{b w m p}$} & $e_{M b p, u s k}$ & $\oplus$ \\
\hline & \multirow{3}{*}{$T F_{\text {održ }}$} & $e_{T o d, b e z}$ & - & & & $e_{M b p, n e u}$ & 0 \\
\hline & & $e_{T o d, d j l}$ & 0 & & \multirow{2}{*}{$N F_{\text {imob }}$} & $e_{\text {Nim,usk }}$ & $\oplus$ \\
\hline & & $e_{\text {Tod,pot }}$ & $\oplus$ & & & $e_{\text {Nim,neu }}$ & 0 \\
\hline & \multirow{3}{*}{$T F_{s t b r}$} & $e_{T s t, n o v}$ & $\oplus$ & & \multirow{2}{*}{$N F_{\text {lokp }}$} & $e_{N l k, s t r}$ & $\oplus$ \\
\hline & & $e_{T s t, d j s}$ & 0 & & & $e_{N l k, b e z}$ & 0 \\
\hline & & $e_{T s t, p s t}$ & 0 & \multirow{11}{*}{ 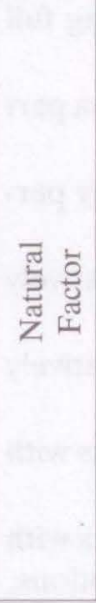 } & \multirow{2}{*}{$P F_{\text {pure }}$} & $e_{P v r, m o m}$ & $\oplus$ \\
\hline \multirow{10}{*}{ 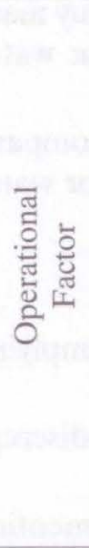 } & $O F_{\text {bter }}$ & $e_{O t r, b v b}$ & $\nabla$ & & & $e_{P v r, m o t}$ & 0 \\
\hline & \multirow{2}{*}{$O F_{u k b l}$} & $e_{O u k, v p k}$ & $\oplus$ & & \multirow{2}{*}{$P F_{o p d b}$} & $e_{P d b, l v d}$ & $\oplus$ \\
\hline & & $e_{\text {Ouk,vpd }}$ & 0 & & & $e_{P d b, l m d}$ & 0 \\
\hline & \multirow{3}{*}{$O F_{t r p b}$} & $e_{O t p, p t k}$ & 0 & & \multirow{2}{*}{$P F_{\text {orgb }}$} & $e_{\text {Por,cil }}$ & 0 \\
\hline & & $e_{O t p, p s t}$ & 0 & & & $e_{P o r, b e z}$ & $\oplus$ \\
\hline & & $e_{\text {Otp,ptd }}$ & $\oplus$ & & \multirow{2}{*}{$P F_{d d a n}$} & $e_{P d d, d a n}$ & $\oplus$ \\
\hline & \multirow{2}{*}{$O F_{i s b l}$} & $e_{O i s, l b n}$ & 0 & & & $e_{P d d, n o c}$ & 0 \\
\hline & & $e_{O i s, l b t}$ & 0 & & \multirow{3}{*}{$P F_{k m o r}$} & $e_{P k m, o c e}$ & $\oplus$ \\
\hline & \multirow{2}{*}{$O F_{b d o k}$} & $e_{O d k, s i m}$ & O & & & $e_{P k m, z a t}$ & 0 \\
\hline & & $e_{O d k, s z b}$ & $\oplus$ & & & $e_{P k m, o b m}$ & 0 \\
\hline
\end{tabular}

Legend: $\bigoplus$-zero harmfulness, $\bigcirc$ - acceptable harmfulness level, $\bigcirc$ - partially acceptable harmfulness level, without ballast, (discharging ballast).

Source: processed by authors 
$-e_{\text {Por, cil }}$ status element for water ballast loading port with detected target organisms;

$-e_{\text {Por,bez }}$ status element for water ballast loading port without detected target organisms;

$-e_{P d d, d a n}$ status element of a ship loading water ballast in port during daylight;

$-e_{P d d, n o c}$ status element of a ship loading water ballast in port during night;

$-e_{P k m, o c e}$ status element of sea category in ocean port - discharging water ballast;

$-e_{P k m, z a t}$ status element of sea category in closed sea - discharging water ballast;

$-e_{P k m, o b m} \quad$ status element of sea category in coastal sea port - discharging water ballast.

\section{Harmfulness levels of status elements}

Assignment of harmfulness level has been performed after the analysis of harmfulness of individual status elements [1], [2], [5], [9], [13], [16]. Four (4)

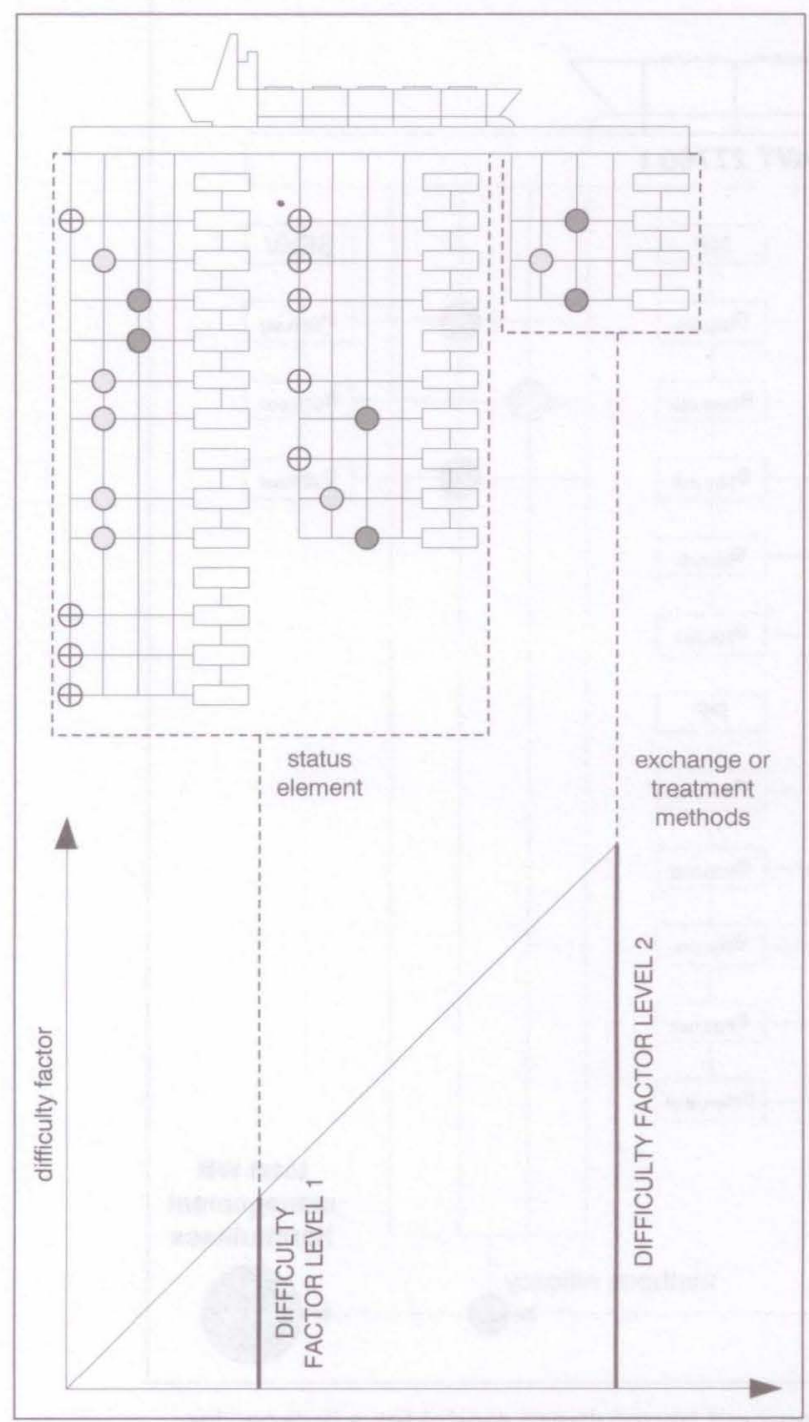

Figure 1 - Difficulty factor evaluation

Source: processed by authors harmfulness levels have been set forth and accepted: unacceptable harmfulness level, partially acceptable harmfulness level, acceptable harmfulness level and level with zero harmful effect.

\section{SCENARIOS OF WATER BALLAST MANAGEMENT HARMFULNESS}

For an objective evaluation of water ballast harmfulness, i. e. interactions of designated harmfulness levels of status elements and of treatment methods, it is necessary to introduce difficulty factors. Upon analysis of the research on water ballast management applied on board, it is evident that the treatment i. e. exchange methods have greater influence on the total harmfulness level of water ballast management than the assigned harmfulness levels of status elements. Consequently, the treatment i. e. exchange methods are assigned level 2 of difficulty factor while the harmfulness levels of status elements are assigned level 1 of difficulty factor.

Figure 1 shows examples of cumulative scenarios of assigned difficulty factors of status elements and treatment or exchange methods on the overall water ballast management harmfulness. It is evident that treatment i. e. exchange methods, having been assigned the diffi-

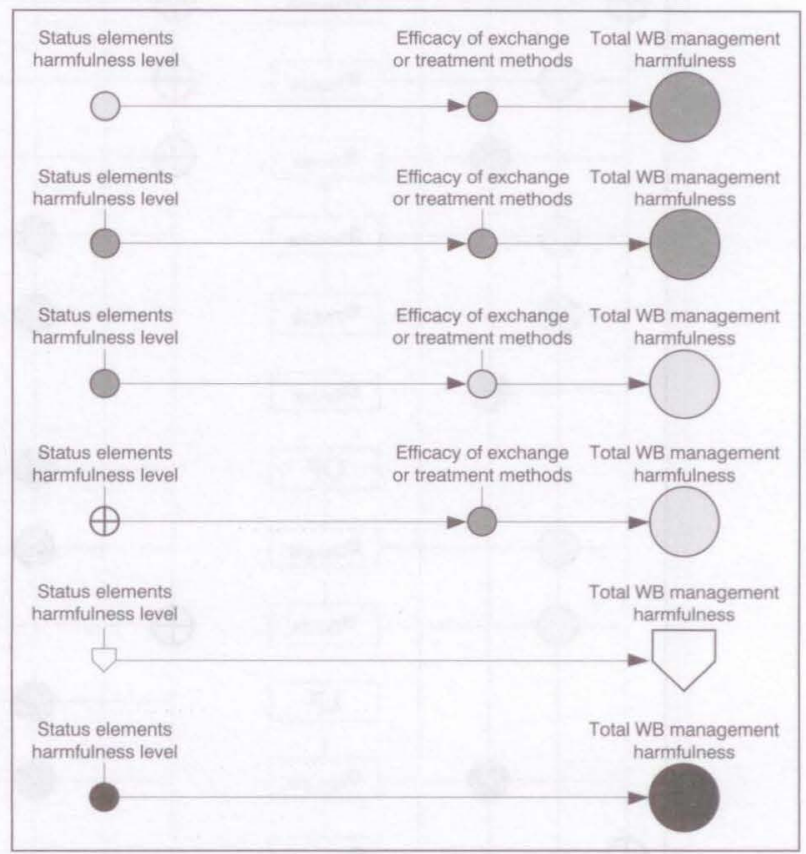

Figure 2 - The impact of difficulty factors on cumulative water ballast management scenarios

Legend:

$\bigoplus$-zero harmfulness,

- acceptable harmfulness level,

- partially acceptable harmfulness level,

- unacceptable harmfulness level,

- zero harmfulness, (for ships not discharging water ballast).

Source: processed by authors 
culty level 2, have greater influence on the total harmfulness level of water ballast management.

\subsection{Elaboration of harmfulness scenarios by general methodology}

By general methodology and comprehensive approach the complex mosaic of all factors, assigned status elements and harmfulness levels is contemplated. Concrete ships can be taken as example, that navigated between certain ports and discharged ballast in port areas. Examples of expected cumulative scenarios are given in Figure 2.

The relevant data required for assessment of status elements levels are obtained by analysis of Ballast Water Reporting Form ${ }^{1}$ [19] for concrete ships and insight into EQUASIS Database Programme [20]. The evaluation of water ballast management methods ${ }^{2}$ was performed after the analysis of efficacy results [2], [6], [7], [10], [12], [14] by assignment of harmfulness levels symbols to water ballast exchange management. Assignment of harmfulness levels symbols was performed in the same manner as with the status elements:
$\oplus$ - zero harmfulness,
- acceptable harmfulness level,
- partially accepted harmfulness level,
- unacceptable harmfulness level.

\subsection{Example of setting up water ballast harmfulness model for a bulk carrier}

- Ship name: Bass Bulker

- Water ballast loading port: Benghazi, Libya

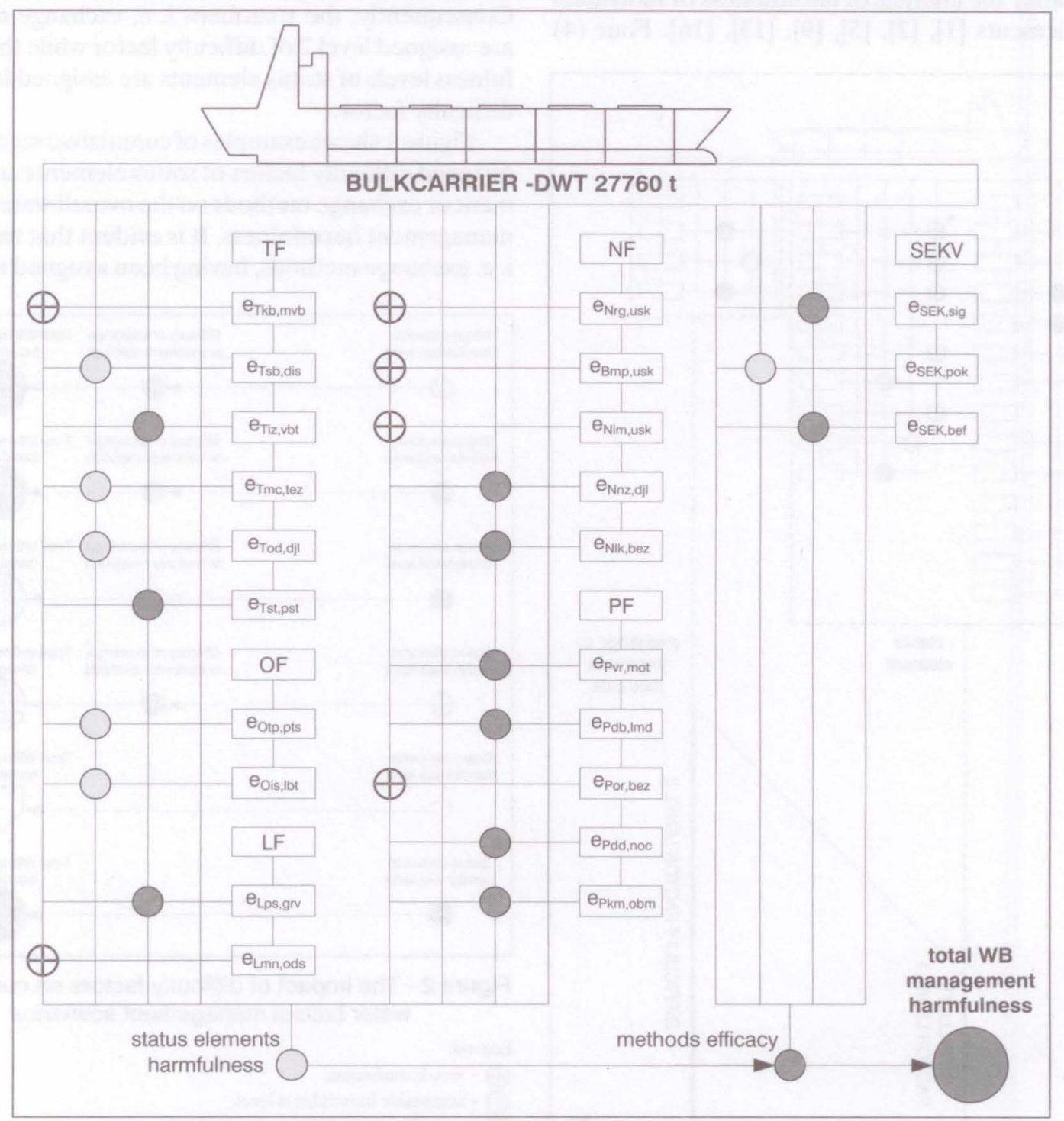

Figure 3 - Comprehensive water ballast management harmfulness model for a bulkcarrier Total water ballast management harmfulness: partially acceptable harmfulness level 
- Water ballast discharging port: Ploče, Croatia

- WB ballast tanks total volume: $9207.4 \mathrm{~m}^{3}$

- WB total volume discharged in port: $8197 \mathrm{~m}^{3}$

- Total number of ballast tanks: 37

- Total number of tanks having discharged WB: 34

- IMO Guidelines (Resolution A. 868(29)) on board: yes

- BWMP implemented: yes

- Exchange method applied: sequential exchange

\section{CONCLUSION}

By a selective approach water ballast management harmfulness scenarios can be obtained eliminating all other relevant factors and status elements. A comprehensive approach allows for incorporation of a complex mosaic of other factors occurring during navigation into the evaluation of harmfulness. This paper elaborates the harmfulness model for a bulkcarrier; however, by means of the methodology as presented it is possible to elaborate a model of any ship that does not discharge or that discharges water ballast in any port worldwide.

The management methodology presented has confirmed the given hypothesis, i. e. dominant factors have not been neglected and a comprehensive approach has been elaborated identifying, defining, elaborating and systematically connecting all impact factors, status elements, harmfulness levels, difficulty factors and other elements influencing water ballast management and necessary for determining the harmfulness levels of water ballast discharged.

There is a rather wide range of possibilities for application of the methodology applied in this paper besides elaboration of water ballast management harmfulness model. The presented methodology is a promising basis for a further more complex interdisciplinary research with a larger number of researchers involved, who will cover their own fields conducting a more thorough research on certain impact factors and status elements that, by application of the methodology proposed, can be systematically connected into a comprehensive water ballast management model.
Dr. sc. ŽELJKO KURTELA

E-mail: zeljko.kurtela@unidu.hr

Sveučilište u Dubrovniku, Pomorski odjel

Ćira Carića 4, 20000 Dubrovnik, Republika Hrvatska

Dr. sc. PAVAO KOMADINA

E-mail: pavao.komadina@pfri.hr

Sveučilište u Rijeci, Pomorski fakultet

Studentska 2, 51000 Rijeka, Republika Hrvatska

\section{SAŽETAK}

\section{METODA PROCJENE ŠTETNOSTI POSTUPANJA VODENIM BALASTOM NA BRODU}

Prepoznavanjem svih dominantnih čimbenika i razvijanjem mozaika svih faktora uvjetovanim aktivnostima plovidbenog poduhvata te mnogim različito dimenzioniranim kriterijima razrađena je metoda procjene štetnosti postupanja vodenim balastom. Raščlambom faktora utjecaja kojima se pridružuju elementi stanja, dodjeljivanjem razina štetnosti elementima stanja, postavljanjem razina težinskih faktora, uvođenjem metoda obrada odnosno izmjena vodenog balasta razvijanju se određeni karakteristični scenariji postupanja prema tipovima brodova. Zbirnim scenarijima sagledava se ukupna štetnost postupanja vodenim balastom. Uvođenjem sveobuhvatnog pristupa razvijaju se scenariji primjenjivi na sve konkretne brodove. Postavljena metoda procjene štetnosti postupanja vodenim balastom primjenjiva je na sve tipove brodova, a ispitana je na različitim tipovima konkretnih brodova koji su ispuštali balast u raznim lukama svijeta.

\section{KLJUČNE RIJEČI}

vodeni balast, štetnost postupanja, faktori utjecaja, elementi stanja, razine štetnosti, scenariji postupanja

\section{REFERENCES}

1. Data collected from concrete ships and Harbour Master Offices.

2. Refers to all water ballast treatment and water ballast exchange methods. Concrete ships used water ballast exchange methods exclusively, while in the near future a more frequent usage of treatment method is to be expected.

\section{LITERATURE}

[1] California Environmental Protection Agency: "Evaluation of Ballast Water Treatment Technology for Control of Nonindigenous Aquatic Organisms”, 2002.

[2] Cangelosi, A. et al.: "Experimental Studies Comparing Biological Effectiveness of Commercially Available Ballast Treatment Systems", 2001.

[3] Cawthron Institute: "Cawthron's Ballast Water Research Programme, Cawthron Report No. 417", 1997.

[4] Cawthron Institute: "Cawthron Report No. 468, Mid Ocean Ballast Water Exchange: Procedures, Effectiveness and Verification", Cawthron PB 2, Nelson, New Zealand, 1998. 
[5] Design Study Report, Northeast-Midwest Institute: "Full Scale Design Studies of Ballast Water Treatment Systems", Washington DC, 2002.

[6] Det Norske Veritas: "Ballast Water Scoping Study", Report No. 2005-0638, Det Norske Veritas, 2005.

[7] Det Norske Veritas: "EMBLA - Enviromental Risk, Management System for Ballast Water Assessment", 1999.

[8] Det Norske Veritas: "Ballast Water Transfer Atlas, Hazard Assessment and Decision Support" Report N0. 99-3166, 1999.

[9] Hallegraeff, G. M.: "Is a $99 \%$ effective ballast treatment sufficient", $1^{\text {st }}$ Glo ballast monograph series No. 4, IMO, London, 2001.

[10] Hege, S.: "BW exchange in the Mediterranean Treatment technology status", Workshop in Opatija, Opatija 2005.

[11] Karaminas, L.: "An Investigation of ballast water management methods with particular emphasis on the risk of the sequential method", Lloyd's Register of Shipping, London 2000.

[12] Kurtela, Ž.: " Methodology of Ballast Water Management on Board", Ph.D. thesis, University of Rijeka, Faculty of Maritime Studies, Rijeka 2008.

[13] Kurtela, Ž., Jelavić, V., Mohović, R.: “An Approach to Selection of Methods for Ships' Ballast Water Treatment”,
"Naše more", (ISSN 0469-6255), 52, pp. 64-74, Dubrovnik, 2005.

[14] Kurtela, Ž., Jelavić, V., Novaković, T.: "Harmful Effect of Discharging Ballast on Marine Environment", "Naše more", (ISSN 0469-6255), 54(1-2)/2007, pp. 1-6, Dubrovnik, 2007.

[15] Macleod, L.: "Risk Associated with the Uncontrolled Discharge of Ships' Ballast and the Legislative Controls Available in Scotland", Reprinted from the Journal of The Chartered Institution of Water and Environmental Management, London, 1995.

[16] Mesbahi, E.: "Latest results from testing seven different technologies under the EU MATROB project - Where do we stand now", 2nd International Ballast Water Treatment R\&D Symposium IMO, London, 2003.

[17] Protocol for Environmental Management: "Domestic Ballast Water Management in Victorian State Waters", EPA Victoria, 2006.

[18] Wright, D. A., et al.: "Some Shipboard Trials of Ballast Water Treatment Systems in the United States", 2nd International Ballast Water Treatment R\&D Symposium IMO, London, 2003.

[19] Ballast Water Reporting Form: African Lion, Bass Bulker, Atlantic Hero, Methane Princes, Mandarin Arrow.

[20] Equasis, Version prod PV 2013, Developed and hosted by France - Ministry for Transport - DAM/SI. 